\title{
The Ethical Duality in Sports: Social and Psychological Aspects of Transgender Participation
}

\author{
Baljinder Singh Bal
}

Guru Nanak Dev University, Amritsar, Punjab, India

KEYWORDS

\begin{abstract}
Historically the notion about the understanding of women has been patriarchal in nature. The postmodern world has an inclination to redefine social mores. The prevailing thought in the $20^{\text {th }}$ and $21^{\text {st }}$ centuries supports the same thesis. The transformation of attitudes appears to be a regular phenomenon in the understanding of the issue at hand, thereby enlivening the motif of unity between the two. Gender, transgender, sexuality, etc., are in a state of transformation, so that to interpret and reinterpret a state of understanding and re-understanding of the issue of participation in sports has multiple significations. Sport in the $21^{\text {st }}$ century constructs inimitable challenges for trans-athletes. A broad spectrum of identities is included under the umbrella of transgender identity. Transsexual or transitioned athletes may pose the greatest challenge to equity in sex-segregated sport competition. The subject under deliberation has a large number of interpretations, all of which center on a need to 'deconstruct' the present structuration of acceptance of sex and gender terminology. There is certainly a need to think and contemplate in broader terms about the meanings that assess the well-defined boundaries between disciplines of research. The present thesis highlights a deconstructive stance.

duality, gender, transgender, gay, sport
\end{abstract}

\section{Introduction}

As we enter the $21^{\text {st }}$ century, it is the best time in history to be born female. In the last 100 years, more progress has been made in the lives of women than was achieved in all the years prior to 1900 . Women now have political, social, educational, and economic opportunities that were denied them from centuries. However, these rights are not enjoyed equally around the world, but slowly - far too slowly in some nations - change for women is beginning to be felt. Even in those countries were freedom is restricted, women are seeing examples of strong women who have taken advantage of opportunities and who serve as role models to their nation. In the field of athletics, we are just now beginning to see what women can do. Science is now telling us that perhaps women's bodies are better suited than men's for some athletic events requiring flexibility and endurance, such as gymnastics and long-distance running. Today the best female athletes can run, swim, and skate faster that the top male athlete of a few decades ago. Studies have shown that since 1964 women's marathon times have dropped $32 \%$ while men's have dropped only $4.2 \%$. If this progress continues, some have even suggested that world-class female runners could possibly catch up with male runners in the $21^{\text {st }}$ century (Ehrenreich 1999). More time and research are needed to discover just how far and fast women can go. 


\section{The gendered context of sports}

The early work on sex difference, as seen in Maccoby and Jacklin's review (Maccoby 1974), assumed dichotomous, biology-based, psychological differences - that males and females are opposites. In practice, dichotomous sex differences are typically interpreted as meaning that we should treat males one way and females another way. Today, consensus holds that psychological characteristics associated with females and males are neither dichotomous nor biology based (Bem 1993, Deaux 1984, Eagley 1987, Gill 1992, 1995, Hyde 1986). Even most biologic factors are not dichotomously divided, but are normally distributed within both females and males. Today, most psychologists recognize the limits of earlier sex difference and gender role approaches and look beyond the male-female and masculine-feminine dichotomies to socialization and social cognitive models for explanations.

\section{Gender and social processes}

In the 1980s, gender research moved away from approaches focusing on sex differences and personality to a more social approach, emphasizing gender beliefs and stereotypes. How people think males and females differ is more important than how they actually differ. Although actual differences between females and males with respect to characteristics such as independence or competiveness are small and inconsistent, we maintain our stereotypes. These gender stereotypes are pervasive. We take minimal differences and exaggerate them into larger perceived differences through the social process. These perceptions exert a strong influence, which may elicit further gender differences. This cycle reflects the feminist position that gender is socially constructed (Bem 1985, Deaux 1987, Spence 1978).

\section{IOC policies on gender}

The way in which sport policies conceptualize, and therefore regulate, gender has undergone significant change. From 1968 until 2000 the International Olympic Committee (IOC) used sex testing at the Olympic Games to verify that athletes competing in women's events were "women." During the 1990s the Gay Games developed gender policies about "men, women, transgender and inter sex" athletes. The broadening of the intellectual sphere relates to the expansion of treatment in term of gender and re-definition. The same thesis is given in further discussion:

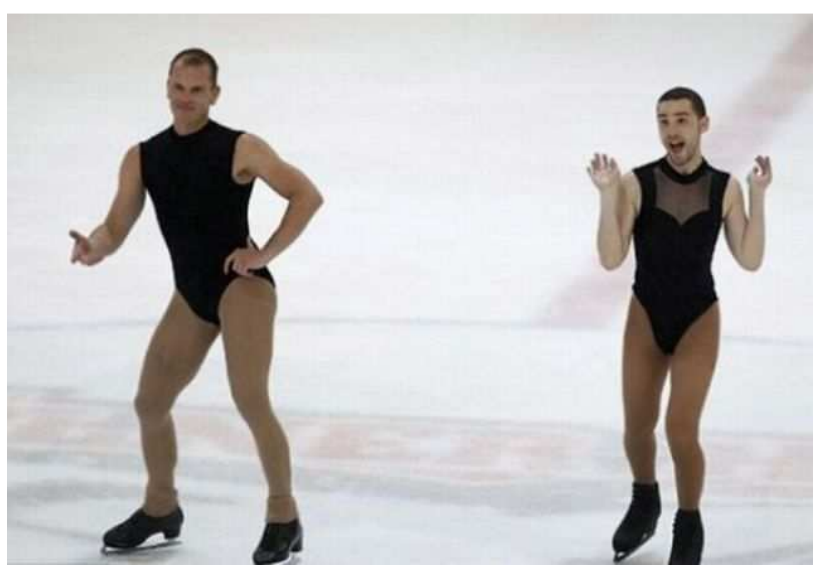

Figure 1. The Gay Games

Source:http:/www.cellarena.in/2011/03/gay-games.html

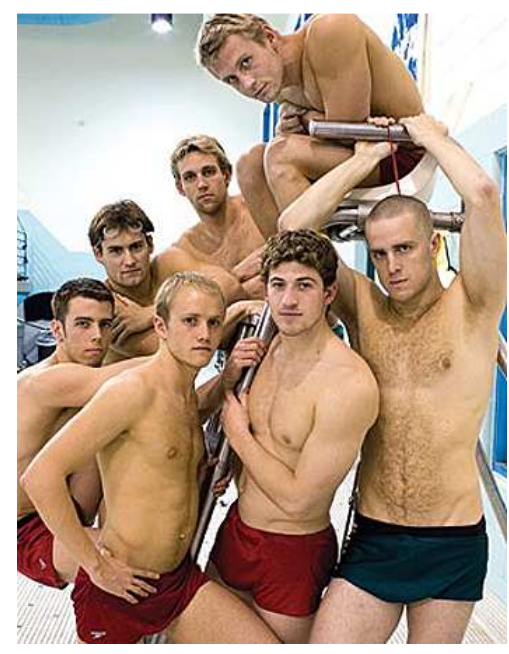

Figure 2. The Gay Games are no laughing matter

Source:http://www.clevescene.com/scene-andheard/archives/2010/07/27/gay-games-updatecleveland-is-not-gay-enough-for-boston 


\section{The brief history of gay athletes}
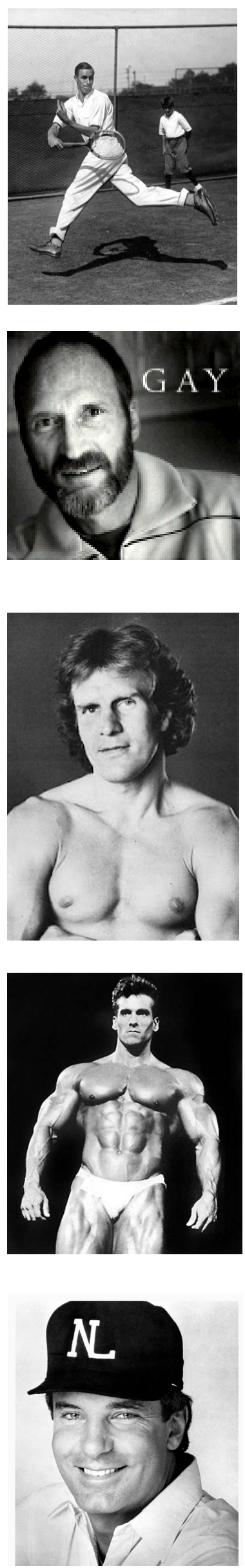

(1920) Bill Tilden, who does not hide his homosexuality, wins the men's singles title at Wimbledon. He goes on to win two more Wimbledon titles, seven U.S. championships, and leads U.S. teams to seven Davis Cup victories. In 1950, a survey of sportswriters names Tilden the greatest tennis player of the half-century. He dies in 1953.

Figure 3. Bill Tilden

Source:http://gayinfluence.blogspot.com/2011/09/bill-tilden tennis-cham pion.html

(1968) Tom Waddell, a 30-year-old Army physician, places sixth in the Olympic decathlon. Waddell, who is openly gay, becomes increasingly involved in gay politics. In 1976, Waddell and his partner Charles Deaton are the first gay men to be featured in the "Couples" section of People magazine. Five years later, Waddell forms San Francisco Arts and Athletics to plan the first "Gay Olympic Games".

Figure 4. Tom Waddell

Source:http://www.publishersweekly.com/978-0-394-57223-9

(1975) David Kopay, an NFL running back who played for five teams (San Francisco, Detroit, Washington, New Orleans, Green Bay) between 1964-72, becomes the first professional team-sport athlete to come out - doing so three years after retiring. He admits his homosexuality during an interview with the now-defunct Washington Star.

Figure 5. David Kopay

Source:http://wwwauthorcharleshenryhall.blogspot.com/2010/10

(1983) Bob Paris wins the Mr. America and Mr. Universe bodybuilding titles. In 1989, he reveals his homosexuality to the bodybuilding community during an interview with Ironman magazine. He also marries his long-time partner Rod Jackson-Paris and discusses the marriage on The Oprah Winfrey Show.

Figure 6. Bob Paris

Source:http://www.criticalbench.com/Bob-Paris.html

(1988) Dave Pallone, a National League umpire, is fired for his alleged involvement with a teenage sex ring. The charges are deemed groundless and the investigation is dropped. According to Pallone, the real reason he was fired was the fact that he was gay.

Figure 7. Dave Pallone

Source:http://gaygamesblog.blogspot.com/2011/04/dave-pallone-on-kobe-bryantincident.html 

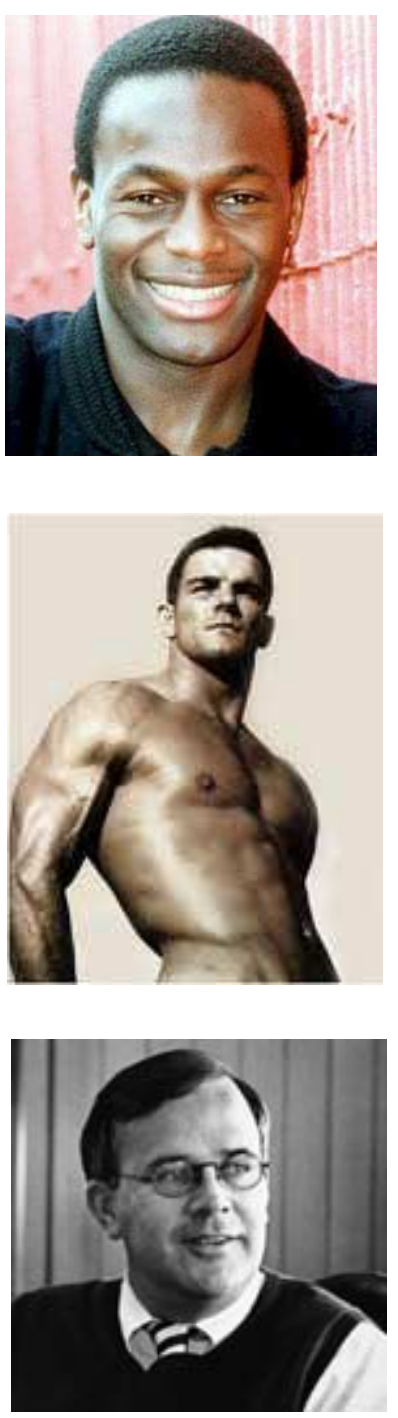

(1988) Justin Fashanu, a top soccer player in Britain, reveals that he is gay. $\mathrm{He}$ is the first athlete in a team sport to come out during his athletic career. After publicly coming out, Fashanu was described by others as "erratic." Fashanu commits suicide in 1998 at the age of 36. His body is found hanging in an abandoned garage in East London.

Figure 8. Justin Fashanu

Source:http://www.advocate.com/News/Daily_News/2010/08/08/Gay_Players_ May_Help_Homophobia_in_Soccer/

(1995) Ian Roberts, one of Australia's most popular rugby players, poses nude for a gay magazine. In the same issue, Roberts speaks about being "part of a different group ... an outsider." He becomes the first major sports figure in Australia to come out. Roberts soon becomes a fixture at a variety of gay events, and his endorsements increase.

Figure 9. Ian Roberts

Source:http://www.afterelton.com/blog/lylemasaki/robert-gant-to play-a-gay-spy

(1998) Michael Muska, a former track-and-field coach at Auburn and Northwestern, is named athletic director at Oberlin College. Muska is the first openly gay man to hold such a position in college sports.

Figure 10. Michael Muska

Source:http://50.19.120.127/home/newsmedia/detail.dot?id=3312207\&parentCat KeyI $=\&$ catKeyI $=$ \&catSet $=$ comm-pr,con-pr

\section{IOC Transgender Policy}

In 2004, the International Olympic Committee (IOC) introduced the Stockholm consensus to allow transsexual athletes to compete at the Olympics. The Stockholm Consensus permits athletes to compete in their transitioned sex if they meet several strict conditions, including having had anatomical surgery with external genitalia changes, being able to verify through medical records a course of hormonal treatment of prescribed length, and having been legally recognized as their transitioned sex. As well, all athletes are required to undergo a case-by-case medical evaluation. This has resulted in a heated debate that there is a competitive advantage for a male who has undergone sex reassignment surgery because of his physical training and development. The IOC's transsexual policy as currently stated is deficient. More specifically, the IOC has not sufficiently demonstrated that transsexual athletes do not have competitive advantages over typically gendered athletes.

\section{Conclusion and practical implications}

Gender has for many years been an issue that surfaces from time to time in women's events at athletic meets. Gender is so ingrained in our athletic structure and practice that to practice effectively we must be aware of the many overt and subtle ways that gender affects everyone in the athletic setting. Transgender athletes are controversial because their existence disrupts essential and binary ideas about sex that are reflected in the historical and contemporary organization of sport. In conclusion, the current deficiency of IOC transgender/ transsexual policies regarding participation of 


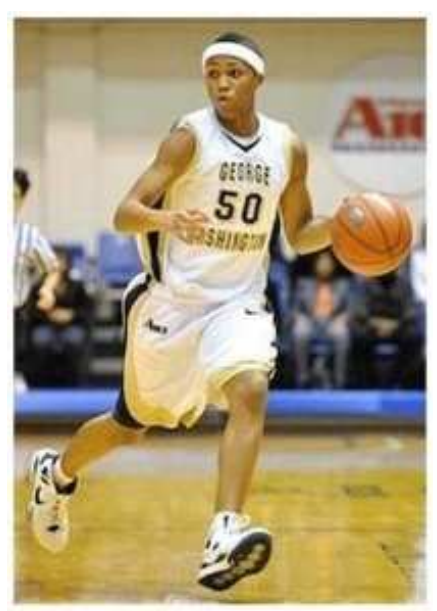

Figure 11. Caster Semenya-South African runner is intersex

Source:http://ourgroupathletes.wordpress.com/2011/09 $/ 21$ /ncaa-adopts-recommendations-for-the-inclusionof-transgender-athletes/

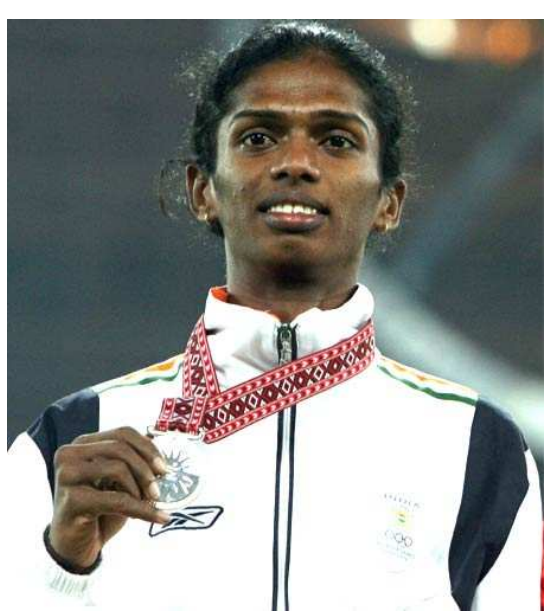

Figure 12. Santhi Soundarajan - Indian athlete fails gender test

Source:http://ourgroupathletes.wordpress.com/ 2011/09/21/ncaa-adopts-recommendations-forthe-inclusion-of-transgender-athletes/

transgender athletes in elite sports creates both the necessity and openings for expertise to create inclusive policies that balance educational values with medico-legal and scientific considerations.

\section{REFERENCES}

Bem, S.L. (1984). Androgny and gender schema theory: A conceptual and empirical integration. In T.B. Sonderegger (Ed.), Psychology and gender: Nebraska Symposium on Motivation, vol. 32 (pp. 179-226). Lincoln, Neb: University of Nebraska Press.

Bem, S.L. (1993). The lenses of gender. New Haven, Conn: Yale University Press.

Deaux, K. (1984). From individual differences to social categories: Analysis of a decade's research on gender. Am Psychol, 39, 105-16.

Deaux, K., Major B. (1987). Putting gender into context: An interactive model of gender-related behaviour. Psychol Rev, 94, 369-89.

Eagley, A.H. (1987). Sex differences in social behaviour: A social role interpretation. Hills Dale, NJ: Lawrence Erlbaum.

Ehrenreich, B. (1999). The real truth about the female body. Times, 153(9), 58.

Gill, D.L. (1992). Gender and sport behavior. In T.S. Horn (Ed.), Advances in sport psychology (pp. 143-60). Champaign, Illinois: Human Kinetics.

Gill, D.L. (1995). Gender issues: A social-educational perspective. In S.M. Murphy (Ed.), Sport psychology intervention (pp. 205-34). Champaign, Illinois: Human Kinetics.

Hyde, J.S., Linn, M.C. (1986). The psychology of gender: Advances through the Meta-Analysis. Baltimore: Johns Hopkins University Press.

Maccoby, E, Jacklin, C. (1974). The psychology of sex differences. Stanford, California: Stanford University Press.

Spence, J.T., Helmreich, R.L. (1978). Masculinity and Femininity. Austin, Texas: University of Texas Press.

Resolution and quality of submitted images is the responsibility of the author.

AUTHOR'S ADDRESS: $\quad$ Baljinder Singh Bal

Department of Physical Education (T)

Guru Nanak Dev University, Amritsar, Punjab, India

Email: bal_baljindersingh@yahoo.co.in 